\title{
DISTRIBUTION OF PHOSPHORUS FORMS IN WATER-PARTICULATE MATERIALS-BOTTOM SEDIMENTS SYSTEM OF THE PRUT RIVER DURING 2009-2012 YEARS
}

\author{
Larisa Postolachi*, Vasile Rusu, Tudor Lupascu \\ Institute of Chemistry of Academy of Sciences of Moldova, 3, Academiei str., Chisinau MD-2028, Republic of Moldova \\ *e-mail: larisapostolachi@gmail.com; phone: (+373 22) 7397 31; fax: (+373 22) 739954
}

\begin{abstract}
Phosphorus is the important nutrient which stimulates the growth of aquatic organisms in water bodies, but in excessive quantities phosphorus has a fertilizing effect that affects both the ecosystem and water quality as whole. A completed scheme for determination of phosphorus forms in water, particulate materials and bottom sediments was applied. The results obtained during of 2009-2012 years were analyzed and systematized, identifying the seasonal and spatial dynamics of phosphorus forms in water, particulate materials and bottom sediments of the Prut River.
\end{abstract}

Keywords: bottom sediments, particulate materials, phosphorus forms, the Prut River.

\section{Introduction}

Phosphorus is an essential nutrient for living organisms. In order to assess the anthropogenic impact on the chemical composition of surface water, the hydro-chemical indicators have been estimated, including either the content of phosphorus-orthophosphates [1,2] or total phosphorus content [3], or the content of both forms [4,5]. Also, the variation of the content of some parameters that characterize the level of eutrophication, the content of nitrogen compounds, chlorophyll and total phosphorus were researched [6-9]. A few studies are focused on research of various phosphorus forms in water and particulate materials [10-12].

Phosphorus concentrations in rivers result from both external inputs and internal loading from the bottom sediments. Its chemistry in sediments is greatly influenced by the oxidation-reduction status (redox potential). Under oxidized conditions, ferric and manganese oxides and hydroxides are important adsorption sites for phosphorus; however, under reducing conditions these minerals are unstable. Mobilization-immobilization processes on the particle surface of sediments occur through interstitial water and its participation. During the desorption process from sediments, phosphorus compounds are accumulated in interstitial water, then according to environmental factors ( $\mathrm{pH}$, oxidationreduction potential Eh, ionic strength, or water mineralization etc.) can be immobilized in the water horizon overlying the bottom sediments.

Phosphorus is a component of various constituents of aquatic ecosystem. But a few studies are focused on the extensive research of phosphorus compounds. Thus, it is often studied the seasonal dynamics of phosphorus compounds in the water-particulate materials system [10-12], in the particulate materials-sediments system [13], in the bottom sediments [14-17], in the interstitial water [18-20], in the water-sediments system [21-23].

The objectives of this work were (i) to evaluate peculiarities of spatial and seasonal dynamics of phosphorus forms for the entirely system water - particulate materials - bottom sediments along the Prut River, (ii) to systematize the results obtained during of 2009-2012 years and (iii) to estimate the level of trophicity and quality of the Prut River.

\section{Material and methods}

During spring and summer of 2009-2012 years the samples of water, particulate materials and bottom sediments were collected along the Prut River (sampling sites: Costesti, Sculeni, Ungheni, Valea Mare, Frasinesti, Poganesti, Leova, Stoianovca, Cahul, Brinza, Caslita-Prut, Giurgiulesti). The bottom sediments with thickness of $0-5 \mathrm{~cm}$ were collected using all-plastic dredge sampler, fresh material being wet-sieved through $2 \mathrm{~mm}$ all-plastic sieve [24]. Then the samples were placed in plastic containers and stored in a portable refrigerator at $4{ }^{\circ} \mathrm{C}$ during transportation to the laboratory.

The scheme for determination of phosphorus forms in water and particulate materials (Fig. 1) according to classification of World Health Organization (WHO) was applied [25]. According to WHO, phosphorus compounds occurred in natural waters are classified into 12 phosphorus forms, by chemical type - (i) orthophosphates, (ii) acid hydrolysable phosphates (poly- and pyrophosphates), (iii) organic phosphorus, (iv) total content, and by physical state - (i) dissolved (filterable), (ii) particulate, (iii) total content.

Additionally, the scheme was tested for estimation of phosphorus content in the bottom sediments [26-28]. The amount of total phosphorus was determined according to U.S. Geological Agency [24]. The content of inorganic phosphorus was determined according to WHO methods for inorganic particulate phosphorus [25]. 


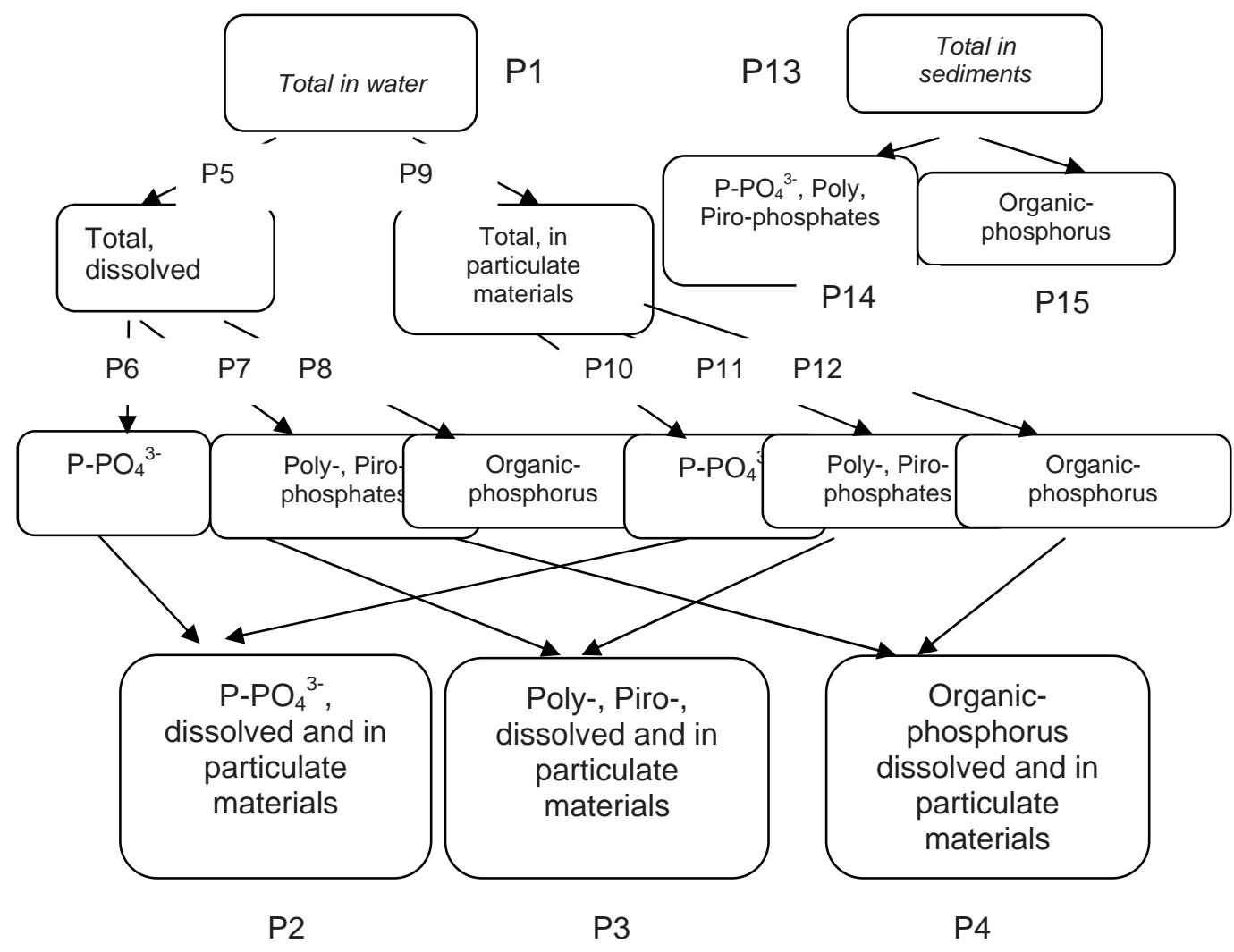

Figure 1. The scheme for analysis of the phosphorus forms in water and particulate materials according to WHO classification (forms P1-P12) [25]. Supplemented scheme for analysis of the phosphorus forms in sediments (forms P13-P15) [26-28].

The content of phosphorus forms in interstitial water was determined after centrifugation of fresh (wet) sediments. There were established amount of orthophosphates, condensed and organic phosphorus according to World Health Organization recommendations [25].

\section{Results and discussion}

Peculiarities of phosphorus content dynamics in water and particulate materials

The spatial dynamics of total phosphorus forms (namely, total P1, total dissolved P5 and total particulate P9) during of 2009-2012 years, in general, had indicated the increase of their amounts along the Prut River (Fig. 2). Seasonal dynamics of the content of phosphorus forms was the same, being established a decrease of total content of phosphorus forms from spring to summer.

The dynamics of dissolved phosphorus forms was less uniform along the Prut River (Fig. 3). During the spring of 2010 and 2011 years the spatial dynamics, in general, had the same trend, being recorded the maximal content of the orthophosphates (P6) and condensed forms (P7) at the middle sector of the river (stations Ungheni, Valea Mare).

For particulate forms of phosphorus (namely, orthophosphates P10 and organic phosphorus P12) an increase of their amounts was recorded along the river, recording the highest values at the lower sector of the river (stations Cahul, Caslita-Prut, Fig. 4). Seasonally, a decrease of particulate phosphorus from spring to summer was established during of 2009-2012 years.

\section{Peculiarities of phosphorus dynamics in bottom sediments and their interstitial water}

The spatial dynamics of phosphorus forms in the bottom sediments had, in general, the same trend during the spring of 2009 - 2011 years (Fig. 5). The higher contents of inorganic form (P14) were registered on the middle course of the Prut River. For organic phosphorus (P15) the highest contents during 2010 and 2011 years were recorded in the bottom sediments on lower course of the river. Multi-annual dynamics showed that the content of phosphorus forms in the bottom sediments was not changed significantly. 


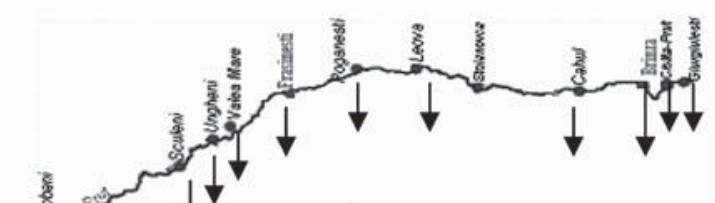

Spring

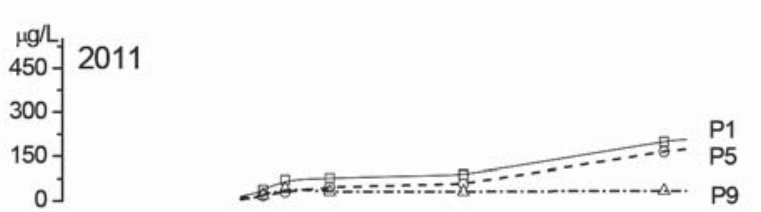

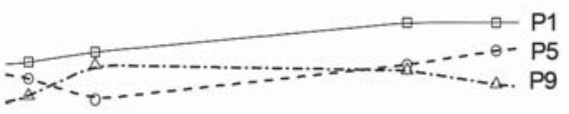

2009

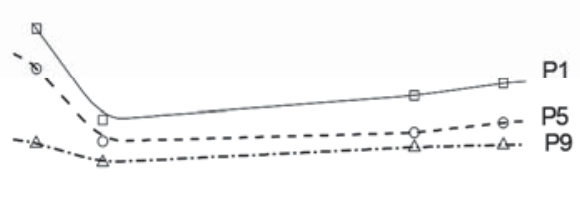

Figure 2. Dynamics of total phosphorus forms along the Prut River (P1, P9 and P5 - total phosphorus, total phosphorus in particulate materials and total dissolved phosphorus, respectively).

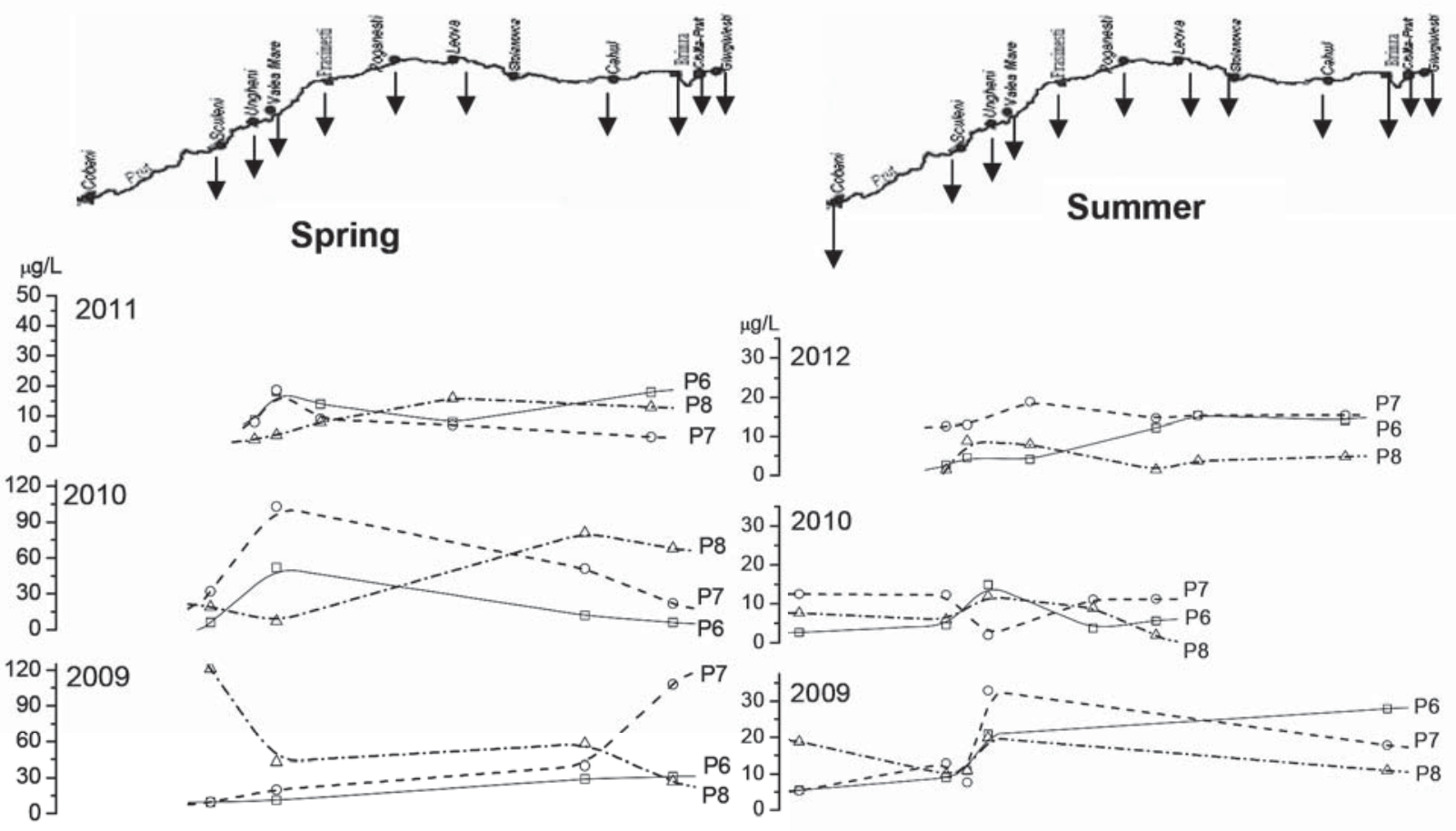

Figure 3. Dynamics of dissolved phosphorus forms along the Prut River (P6, P7 and P8-orthophosphate, condensed forms (poly- and pyrophosphates) and organic-phosphorus, respectively). 

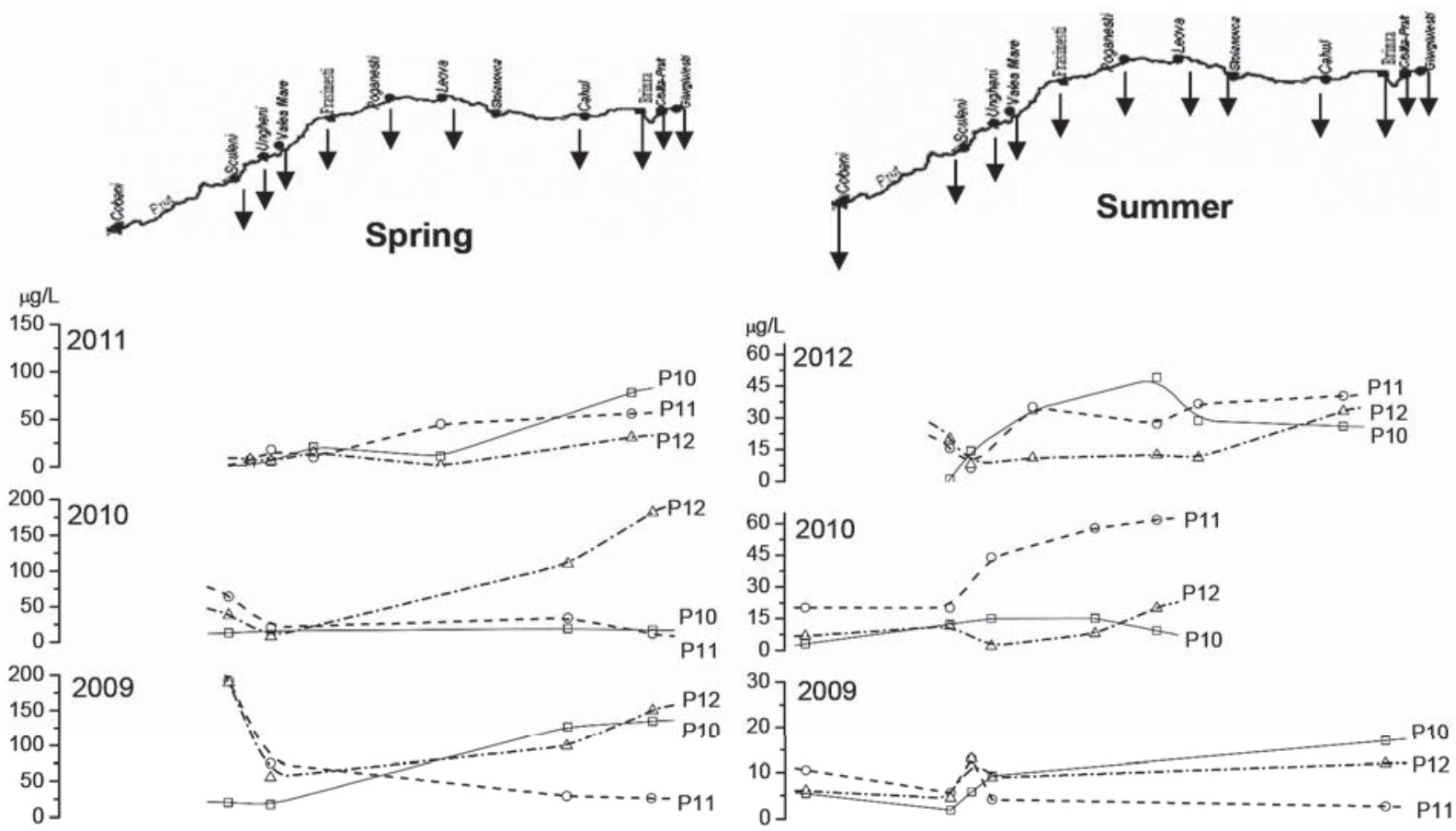

Figure 4. Dynamics of particulate phosphorus forms along the Prut River (P10, P11, P12 - orthophosphates, condensed forms and organic-phosphorus, respectively).

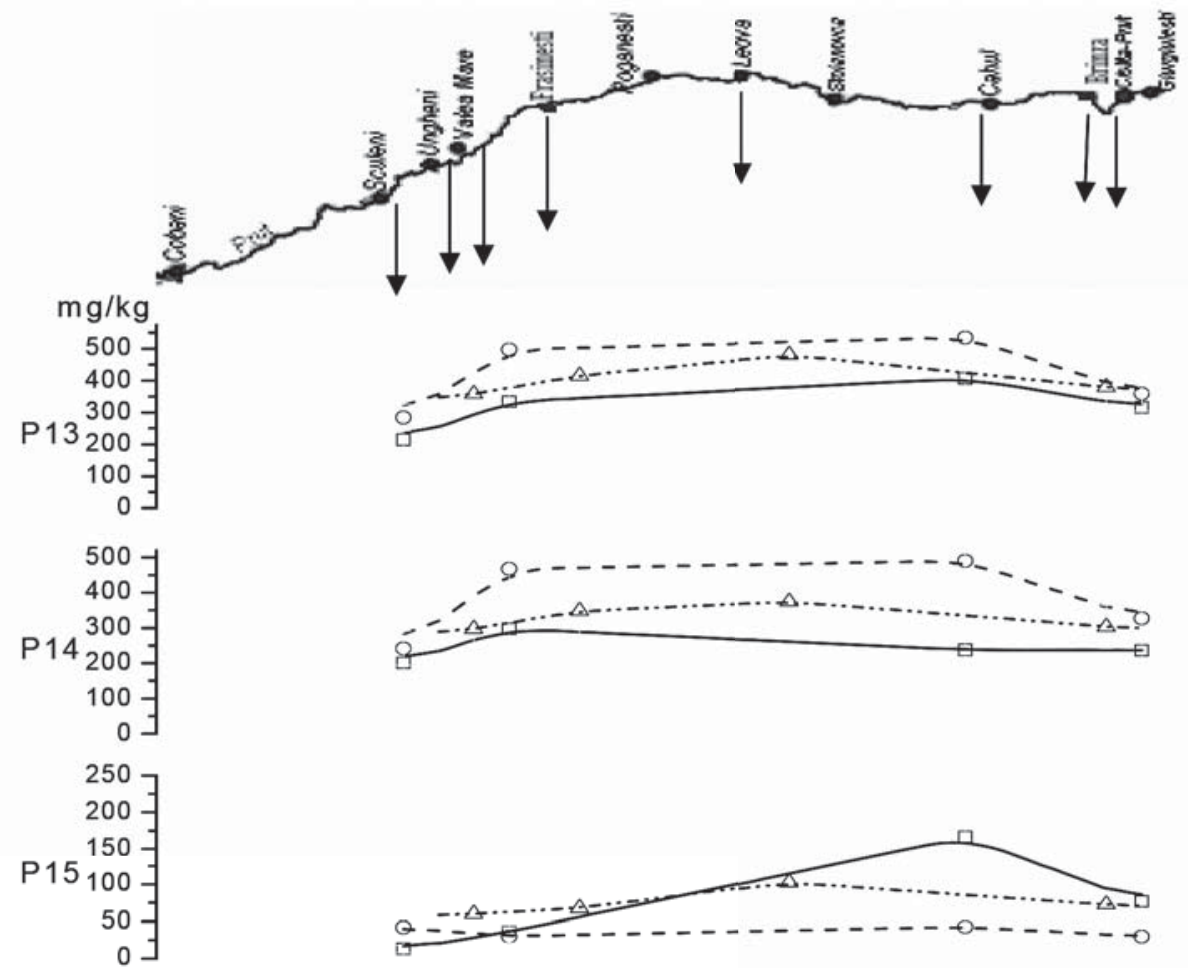

Figure 5. Dynamics of phosphorus forms in bottom sediments along the Prut River, spring ( $\square$ 2009, $\bigcirc$ 2010, $\triangle$ 2011). Phosphorus forms in bottom sediments:

P13 - total phosphorus, P14 - inorganic phosphorus, P15 - organic phosphorus.

During the summer the spatial dynamics of phosphorus forms in bottom sediments was less uniform along the Prut River (Fig. 6). Seasonal dynamics of phosphorus forms in bottom sediments was more pronounced during 2009 and 2010, being registered the tendency of decreasing of inorganic phosphorus and the tendency of increasing of organic phosphorus from spring to summer. 
Ratio of inorganic: organic phosphorus (P14 : P15) in bottom sediments was similar during 2004, 2009, 2010 and 2011 years (Fig. 7), being recorded the predominance of the inorganic phosphorus which constituted about $65-95 \%$ of total amount. Also, the increasing tendency of the percentage of organic phosphorus from spring to summer was registered.
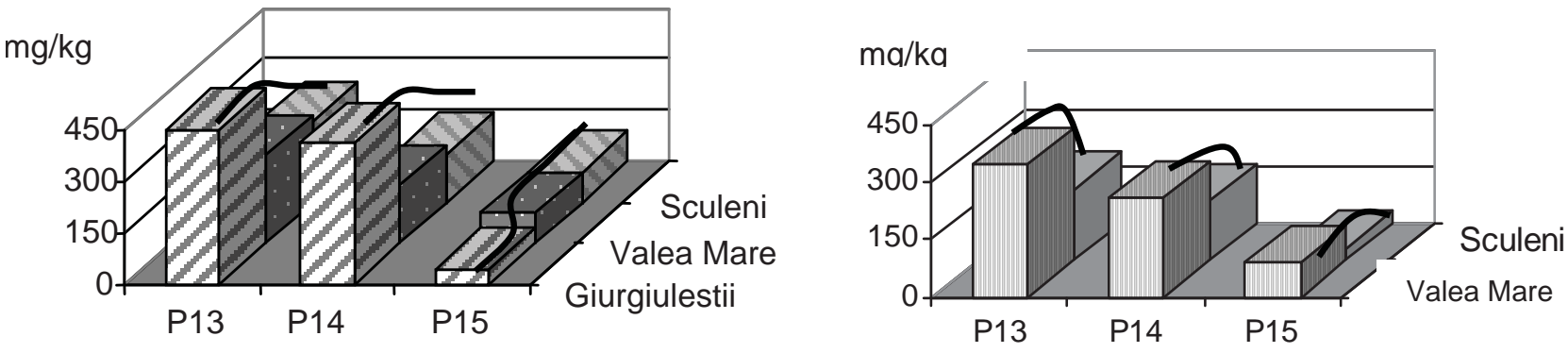

Figure 6. Dynamics of phosphorus forms in bottom sediments along the Prut River (summer).

Phosphorus forms in bottom sediments:

P13 - total phosphorus, P14 - inorganic phosphorus, P15 - organic phosphorus.
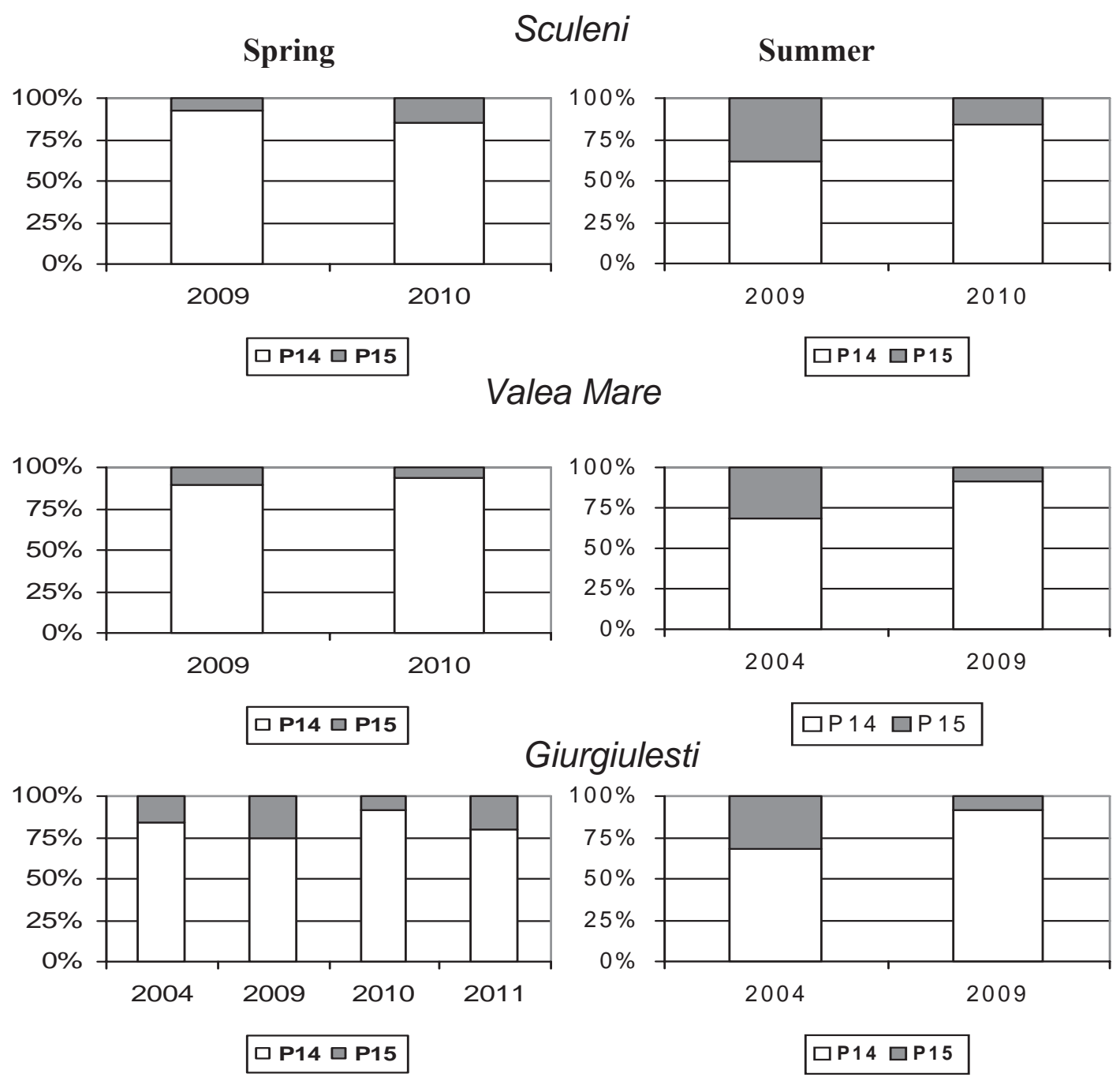

Figure 7. Proportions of inorganic (P14) and organic (P15) phosphorus in bottom sediments along the Prut River during the spring and summer of 2004, 2009, 2010 and 2011 years. 
Phosphorus content in interstitial water was computed per volume of interstitial water (IW) extracted from $1 \mathrm{~kg}$ of bottom sediments (Fig. 8). Seasonal dynamics of phosphorus forms in interstitial water was more pronounced during 2009 and 2010, being registered the tendency of increasing of inorganic phosphorus and the tendency of decreasing of organic phosphorus from spring to summer.

During the spring of 2009 year the predominance of the organic phosphorus in interstitial water of bottom sediments was recorded which constituted about $45-78 \%$ of total phosphorus amount, while during the summer the proportion of organic phosphorus was lower (1.7-13\% of total amount, Fig. 9).

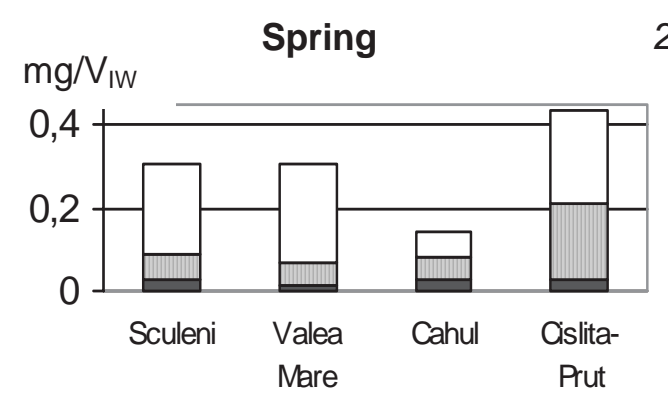

$\square$ P6 $\square$ P7 $\square$ P8
Summer

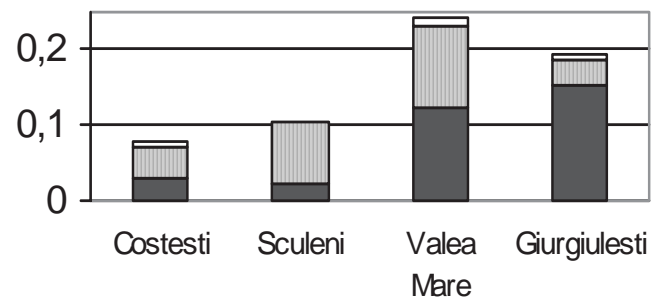

P6 $\square$ P7 $\square$ P8 $\mathrm{mg} / \mathrm{V}_{\mathrm{IW}}$

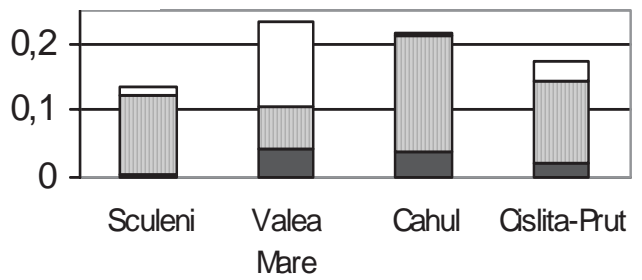

P6 $\square$ P7 $\square$ P8
2010

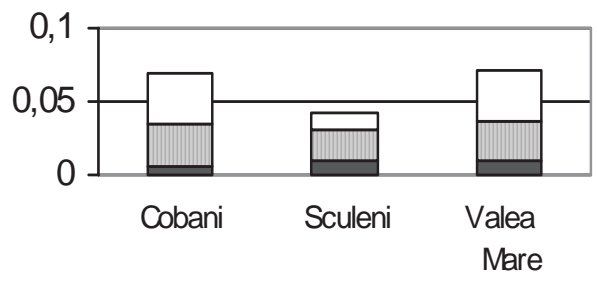

P6 $\square$ P7 $\square$ P8

Figure 8. Dynamics of phosphorus forms $\left(\mathrm{mg} / \mathrm{V}_{\mathrm{IW}}\right)$ in interstitial water (IW) of bottom sediments along the Prut River during the spring and summer of 2009 and 2010 years. Data are computed per volume of interstitial water (IW) extracted from $1 \mathrm{~kg}$ of bottom sediments.

Phosphorus forms in interstitial water:

P6 - orthophosphates, P7 - condensed forms (poly- and pyrophosphates), P8 - organic phosphorus.

\section{Level of trophicity and quality of the water}

The large amounts of phosphorus compounds in aquatic ecosystems have the fertilizing effect that affects eutrophication degree. The European Community Directive 91/676/EEC recommends that the level of eutrophication in rivers should be determined on the basis of quality parameters, such as nitrate, phosphorus compounds, chlorophyll, oxygen etc. In accordance with the recommendations [29] eutrophication level is estimated according to the total phosphorus content (Tab. 1), while according to further recommendations [30] the level of eutrophication for rivers is estimated on the basis of soluble reactive phosphorus (Tab. 2).

Table 1.

Parameters used by the Member States of EC for assessment of eutrophication in rivers [29].

\begin{tabular}{|c|c|c|c|c|}
\hline \multirow{2}{*}{ Parameters } & \multicolumn{4}{|c|}{ Quality grade thresholds (eutrophication levels), mgP/L } \\
\cline { 2 - 5 } & $\begin{array}{c}\text { I } \\
\text { (Ultra-Oligotrophic) }\end{array}$ & $\begin{array}{c}\text { II } \\
\text { (Oligotrophic) }\end{array}$ & $\begin{array}{c}\text { III } \\
\text { (Mesotrophic) }\end{array}$ & $\begin{array}{c}\text { IV } \\
\text { (Eutrophic) }\end{array}$ \\
\hline Total phosphorus (P1) & $0-0.05$ & $0.05-0.2$ & $0.2-0.5$ & $0.5-1$ \\
\hline
\end{tabular}




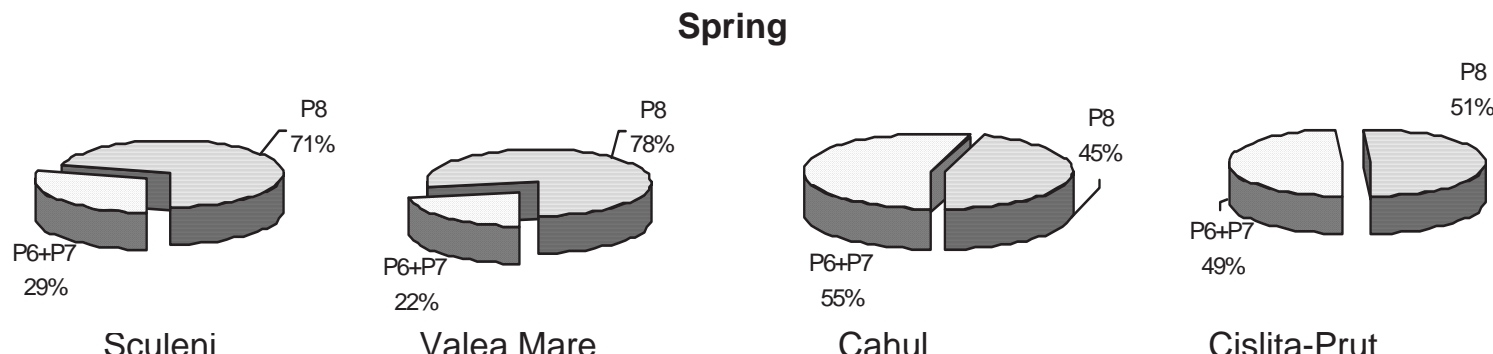

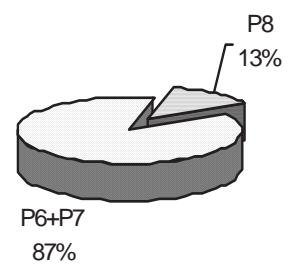

Cobani

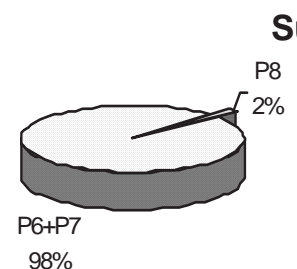

Sculeni

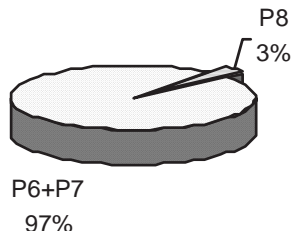

Valea Mare

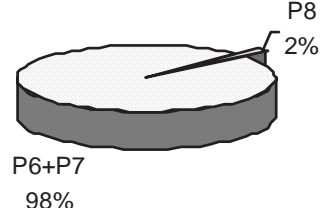

Giurgiulesti

Figure 9. Proportions of inorganic (P6+P7) and organic (P8) phosphorus in interstitial water of bottom sediments along the Prut River during the spring and summer of 2009 year.

Directive threshold values for SRP used in Northern Ireland

Table 2. for assessment of eutrophication in rivers [30].

\begin{tabular}{|c|c|c|c|}
\hline \multirow{2}{*}{ Parameters } & \multicolumn{3}{|c|}{ Quality grade thresholds (eutrophication levels), mgP/L } \\
\cline { 2 - 4 } & $\begin{array}{c}\text { I } \\
\text { (Oligotrophic) }\end{array}$ & $\begin{array}{c}\text { II } \\
\text { (Mesotrophic) }\end{array}$ & $\begin{array}{c}\text { III } \\
\text { (Eutrophic) }\end{array}$ \\
\hline Orthophosphates (SRP, P6) & $0-0.02$ & $0.02-0.10$ & $>0.10$ \\
\hline
\end{tabular}

On the basis of the total phosphorus content (Tab. 1) and orthophosphates content (Tab. 2) the eutrophication level of the Prut River should be attributed to oligotrophic-mesotrophic level of eutrophication.

The quality of surface waters in Romania is regulated by Order 1146/2002 which includes five-quality classes [31]. The values specified for each class correspond to the maximum allowable for respective quality class (Tab. 3). On the basis of presented data in this work, the water of the Prut River should be attributed to the class I of quality according to phosphorus-orthophosphate content (P6), and to classes I-II of quality according to the content of total phosphorus (P1).

Table 3.

Quality classification of surface waters by phosphorus content (Order 1146/2002, [31]).

\begin{tabular}{|c|c|c|c|c|c|}
\hline \multirow{2}{*}{ Limit value for classes } & \multicolumn{5}{|c|}{ Class of quality, mgP/L } \\
\cline { 2 - 6 } & I & II & III & IV & V \\
\hline Orthophosphates (P6) & 0.05 & 0.1 & 0.2 & 0.5 & $>0.5$ \\
\hline Total phosphorus (P1) & 0.1 & 0.2 & 0.4 & 1 & $>1$ \\
\hline
\end{tabular}

According to the European Commission (UKTAG, 2003, [32]), the tolerated threshold (the arithmetic means calculated over a three-year period) for soluble reactive phosphorus SRP (mainly orthophosphates) is $0.20 \mathrm{mg} / \mathrm{L}$ (Tab. 4). The orthophosphate concentrations (the form P6, Fig. 3) registered for the Prut River during of 2009-2012 years didn't exceed this ecological threshold for eutrophication, the value of arithmetic mean being about $0.13 \mathrm{mg} / \mathrm{L}$. 
Table 4.

Phosphorus threshold values of SRP (mgP/L) (UKTAG, 2003, [32]).

\begin{tabular}{|c|c|c|c|}
\hline Risk category & Not at risk & Probably at risk & At risk \\
\hline Parameters & & & $>0.04$ \\
\hline
\end{tabular}

Actually, there aren't yet established any quality criteria for phosphorus content in the bottom sediments. Also, the criteria for phosphorus content in the interstitial water aren't standardized. In the study [33], the preliminary quality parameters of phosphorus-orthophosphates in the interstitial water of bottom sediments were proposed (Tab. 5).

According to the presented data for the content of phosphorus-orthophosphates in the interstitial water of sediments (Fig. 8), the level of eutrophication of the Prut River could be attributed to the oligotrophic level (P6 <0.1mgP/L), episodically (during the summer of 2009 year) to the mesotrophic level of eutrophication. This level of eutrophication is similar to those established on the basis of the content of phosphorus-orthophosphates in water.

Table 5.

Preliminary parameters of phosphorus-orthophosphates content $(\mathrm{mgP} / \mathrm{L})$ in the interstitial water $(0-5 \mathrm{~cm}$ thickness of sediments) [33].

\begin{tabular}{|c|c|c|c|c|c|}
\hline Limit value & Oligotrophic & Mesotrophic & Eutrophic & $\begin{array}{c}\text { Eutrophic- } \\
\text { hypertrophic }\end{array}$ & Hypertrophic \\
\hline $\begin{array}{c}\text { Orthophosphates (SRP, } \\
\text { P6) }\end{array}$ & $<0.10$ & $0.10-0.25$ & $0.25-1.00$ & $1.00-2.50$ & $>2.50$ \\
\hline
\end{tabular}

\section{Conclusions}

The scheme for determination of phosphorus forms in water and particulate materials according to World Health Organization classification was evaluated. Additionally, this scheme was tested for estimation of phosphorus content in bottom sediments. The supplemented scheme allows the analysis of the phosphorus forms for the entirely system "water - particulate materials - bottom sediments", extending possibilities for interpretation of phosphorus dynamics in natural waters.

The peculiarities of the spatial and seasonal dynamics of phosphorus in the water-particulate materials-sediments system during of 2009-2012 years along the Prut River were established. It was found an increasing trend of total dissolved phosphorus and in particulate materials along the Prut River. The maximum of dissolved phosphorus forms recorded on middle sector of the river (Valea Mare-Stoianovca) indicates the presence of pollution sources.

On the basis of obtained data, the water of the Prut River should be attributed to classes I-II of quality according to Romanian standards. The eutrophication level of the Prut River should be attributed to oligotrophic-mesotrophic level of eutrophication according to UE directives. According to the European Commission, the orthophosphate concentrations registered for the Prut River during of 2009-2012 years didn't exceed this ecological threshold for eutrophication. Actually, there are not yet established any quality criteria for phosphorus content in the bottom sediments.

\section{Acknowledgements}

This work has been supported by the international program SCOPES 2009-2012. Swiss National Science Foundation. Joint Research Project "Xenobiotic Input to the Prut River (XENOPRUT)".

\section{References}

[1] Petre, J.; Vasile, G.; Cruceru, L.; Nicolau, M.; Mirita, M.; Iancu V. The evolution of water and sediments quality from the Danube delta in the period April-October of the years 2003-2004, Proc. 13th Int. Symp. on Environment and Industry, Bucharest, 2005, pp. 288-294.

[2] Hounsou, M.; Ahamide, B.; Agbossou, E.K.; Gaiser T. Evaluation of water quality in the Oueme River (Benin), Environmentalist, 2011, 31, pp. 407-415.

[3] Pascu, L.; Petre, J.; Vasile, G.; Vasile, I.; Dumitru, S.; Cristina, D.; Nastac, E.; Cruceru, L.; Nicolau, M.; Evaluation of physical-chemical quality characteristics of surface water and sediments from the Danube Delta in period April 2006-August 2009, Proc. 15th Int. Symp. on Environment and Industry, Bucharest, 2009, vol. 1, pp. 318-324.

[4] Hamchevici, C.; Moldovan, C.; Popescu, V.; Constantinescu, L.; Dumitrache, F. Water quality along Romanian sector of the Danube River during of 1996-2005 years, Hidrotehnica, 2010, 55(3), pp. 26-33 (Rom).

[5] Baborowski, M.; Buttner, O.; Einax, J. Assessment of Water Quality in the Elbe River at Low Water Conditions Based on Factor Analysis, Clean - Soil, Air, Water, 2011, 39(5), pp. 437-443.

[6] Chmiel, S.; Głowacki, S.; Michalczyk, Z.; Sposób, J. Some issues in the assessment of eutrophication of river 
waters as a consequence of the construction of a storage reservoir (on the example of the Bystrzyca River), Ecohydrology\&Hydrobiology, 2009, 9, pp. 175-179.

[7] Jung, N. C.; Popescu, I.; Price, R.K.; Solomatine, D.; Kelderman, P.; Shin, J.K. The use of the A.G.P. test for determining the phytoplankton production and distribution in the thermally stratified reservoirs: The case of the Yongdam reservoir in Korea, Environmental Engineering and Management Journal, 2011, 10(11), pp. 16471657.

[8] Jung, N.C.; Popescu, I.; Kelderman, P.; Solomatine, D.P.; Price, R.K. Application of Model Trees and Other Machine Learning Techniques for Algal Growth Prediction in Yongdam Reservoir, Republic of Korea, Journal of Hydroinformatics, 2010, 12(3), pp. 262-274.

[9] Hu, J.; Qiao, Y.; Zhou, L.; Li, S. Spatiotemporal distributions of nutrients in the downstream from Gezhouba Dam in Yangtze River, China, Environmental Science and Pollution Research, 2011, 19, pp. 2849-2859.

[10] Selig, U.; Michalik, M.; Hubener, T. Assessing P status and trophic level of two lakes by speciation of particulate phosphorus forms, Journal of Limnology, 2006, 65(1), pp. 17-26.

[11] Noe, G.; Harvey, J.W.; Saiers, J.E. Characterization of suspended particles in Everglades wetlands, Limnology and Oceanography, 2007, 52(3), pp. 1166-1178.

[12] Yoshimura, T.; Nishioka, J.; Saito, H.; Takeda, S.; Tsuda, A.; Wells, M.L. Distributions of particulate and dissolved organic and inorganic phosphorus in North Pacific surface waters, Marine Chemistry, 2007, 103, pp. $112-121$.

[13] Iglesias, M.L.; Devesa-Rey, R.; Pérez-Moreira, R.; Díaz-Fierros, F.; Barral, M.T. Phosphorus transfer across boundaries: from basin soils to river bed sediments, Journal of Soils and Sediments, 2011, 11, pp. 1125-1134.

[14] Wiratchapun, P.; Dharmvanij, S.; Charusiri, P. Comparison of Phosphorus Partitioning Results in Estuarine Sediments by Sedex, Modified Sedex and Agemian Extraction Schemes, Journal of Scientific Research of Chulalongkorn University, 2003, 28(1), pp. 23-33.

[15] Matuszewska, K.; Białkowska, I.; Bolałek, J. Interdependence between phosphorus forms in sediments and iron in interstitial waters in the Gulf of Gdańsk, International Journal of Oceanography and Hydrobiology, 2003, XXXII (1), pp. 5-14.

[16] Fang, T.; Chena, J.L.; Huhb, C.A. Sedimentary phosphorus species and sedimentation flux in the East China Sea, Continental Shelf Research, 2007, 27, pp. 1465-1476.

[17] Barral, M.; Devesa-Rey, R.; Ruiz, B.; Díaz-Fierros, F. Evaluation of Phosphorus Species in the Bed Sediments of an Atlantic Basin: Bioavailability and Relation with Surface Active Components of the Sediment, Soil and Sediment Contamination, 2012, 21(1), pp. 1-18.

[18] Jahnke, R.A.; Alexander, C.R.; Kostka, J.E. Advective pore water input of nutrients to the Satilla River Estuary, Georgia, USA, Estuarine, Coastal and Shelf Science, 2003, 56, pp. 641-653.

[19] Jahnke, R.; Richards, M.; Nelson, J.; Robertson, C.; Rao, A.; Jahnke D. Organic matter remineralization and porewater exchange rates in permeable South Atlantic Bight continental shelf sediments, Continental Shelf Research, 2005, 25, pp. 1433-1452.

[20] Adeyemo, O.; Adedokun, O.A., Yusuf, R.K.; Adeleye, E.A. Seasonal changes in physico-chemical parameters and nutrient load of river sediments in Ibadan City, Nigeria, Global NEST Journal, 2008, 10(3), pp. 326-336.

[21] Voinea, E.; Petre, J.; Lucaciu, I.; Cruceru, L.; Nicolau, M.; Gabriela, V.; Mitrita, M.; Rusu, G.; Ciurcanu, I.; Iancu V. The temporal and spatial dynamics of the physico-chemical quality characteristics and the biotic communities structure in the aquatic ecosystems from Danube Delta biosphere, Proc. 12th Int. Symp. on Environment and Industry, Bucharest, 2003, (CD).

[22] Guangwei, Z.; Qin, B.; Zhang, L. Phosphorus forms and bioavailability of lake sediments in the middle and lower reaches of Yangtze River, Science in China: Series D Earth Sciences, 2006, 49, pp. 28-37.

[23] Kowalczewska-Madura, K.; Dondajewska, R.; Gołdyn, R. Changes of phosphorus concentration in bottom sediments and in overlying water of two strongly eutrophicated lakes in Wielkopolska Region, Limnological Review, 2007, 7, pp. 205-211.

[24] Techniques of water-resources investigations of the United States Geological Survey, Fishman M, Friedman L (Eds) Book 5, 3d edition, Washington, 1989, 545 p.

[25] Madera, V.; Allen, H. E.; Minear, R. A., Eds. Examination of Water for Pollution Control, World Health Organization. Pergamon Press: Copenhagen, Denmark, 1982; 1st Ed., vol. 2; pp. 310-319.

[26] Rusu, V.; Postolachi, L.; Lupascu, T. Phosphorus content in water, particulate materials and sediments of river Prut, Environmental Engineering and Management Journal, 2006, 5, pp. 591-596.

[27] Rusu, V.; Postolachi, L. Monitoring of phosphorus content in "water-particulate materials-bottom sediments system” for river Prut, In Air and Water components of environment, G. Pandi and F. Moldovan (Eds), 2011, pp. 206-213.

[28] Rusu, V.; Postolachi, L.; Povar, I.; Alder, A.; Lupascu, T. Dynamics of phosphorus forms in the bottom sediments and their interstitial water for the Prut River (Moldova), Environmental Science and Pollution Research, 2012, 19, pp. 3126-3131. 
[29] "Nitrates" Directive 91/676/EEC, Status and trends of aquatic environment and agricultural practice, Development guide for Member States' reports, ISBN 92-828-9379-0.

[30] Review of 2007-2010, Action Programme for the Nitrates Directive. Northern Ireland. Recommendations from the Scientific Working Group. On-line at: http://www.doeni.gov.uk/nap_review_final.pdf.

[31] Order, 2002, Order of the Minister of Waters and Environmental Protection No. 1146/2002 on the approval of the Norm regarding the reference objectives for the classification of the quality of the surface waters, published in Romanian Official Monitor no 197 from $27^{\text {th }}$ March 2003 (Rom).

[32] UKTAG (2003), Guidance on selection of risk assessment criteria in relation to biological classification schemes for rivers, (Working Draft), UK Technical advisory group on the water framework directive.

[33] Maassen, S.; Uhlmann, D.; Roske, I. Sediment and pore water composition as a basis for the trophic evaluation of standing waters, Hydrobiologia, 2005, 543, pp. 55-70. 